\title{
Deep-sea parasitic nematodes of the genus Trophomera Rubtsov et Platonova, 1974 (Benthimermithidae) from the Equatorial Atlantic, with the descriptions of two new species
}

\author{
Dmitry M. Miljutin
}

Received: 15 October 2009/Revised: 30 June 2010/Accepted: 5 September 2010/Published online: 17 September 2010

(C) Springer-Verlag and AWI 2010

\begin{abstract}
Nematode females of the genus Trophomera (Benthimermithidae) from the collection of the Smithsonian's National Museum of Natural History (Washington, DC, USA) were examined. Nematodes were collected in different parts of the Western Atlantic (Hatteras Abyssal Plain, Brazil Basin, and Argentina Basin) from depths of 467-5,223 m. Two new species are described. Body length of $T$. americana sp. $\mathrm{n}$. is $3,250-4,470 \mu \mathrm{m}$; posterior end conical with rounded tip; cephalic setae about 3-4 $\mu \mathrm{m}$ long; trophosome consisting of several longitudinal rows of large cells; ovaries reflected; mature eggs $35 \mu \mathrm{m}$ in diameter. Body length of $T$. longiovaris sp. n. is $7,870-15,400 \mu \mathrm{m}$; posterior end conical with rounded tip; cephalic sensilla $7 \mu \mathrm{m}$ long; mouth opening vestigial, present as very narrow apical pore; pharynx devoid of internal lumen and muscular envelope; midgut represents a trophosome without internal lumen; trophosomal cells arranged in 3-4 longitudinal rows; rectum and anus vestigial; female reproductive system didelphic, amphidelphic, very long, occupying about 0.8 total body length; ovaries telogonic, outstretched; oviducts very long, repeatedly folded across body axis; proximal parts of oviducts being than distal ones, uterus distinctly formed. New finds of two known species, T. arnauidi and T. marionensis, are also recorded and described.
\end{abstract}

Communicated by Peter Funch.

D. M. Miljutin ( $\square)$

Forschungsinstitut Senckenberg, Senckenberg am Meer,

Deutsches Zentrum für Marine Biodiversitätsforschung,

Südstrand 44, 26382 Wilhelmshaven, Germany

e-mail:dmiljutin@senckenberg.de
Keywords Benthimermithidae - Benthimermis .

Deep-sea $\cdot$ Nematoda $\cdot$ Parasite $\cdot$ Taxonomy $\cdot$ Trophomera

\section{Introduction}

Benthimermithids are marine nematodes that have a larval stage parasitizing the body cavity or internal organs of a wide spectrum of mainly deep-sea invertebrates (nematodes, polychaetes, priapulids, and crustaceans). These worms possess a vestigial mouth opening and pharynx (the latter is devoid of a muscular envelope and a functional axial internal lumen), and their midgut also has no internal lumen. For this reason, it is presumed that the parasitic stages absorb nutrients through the body surface. The midgut is transformed into a trophosome, which consists of large cells with numerous internal lipid-containing vesicles, and serves as a depot for nutrients (Chesunov 1997; Miljutin and Tchesunov 2001). Late parasitic stages can occupy the entire body of their hosts and may possible cause the death of the host. Before the terminal molt, benthimermithids exit their host to the external environment, where they do not feed but do reproduce. Evidently, adult benthimermithids consume the nutrients accumulated in their trophosome during the larval parasitizing stage, because senile specimens are virtually lacking in lipidcontaining vesicles inside their trophosome, whereas the trophosomes of young, virgin adults are tightly packed with such vesicles. The hosts of the majority of the described benthimermithids are still unknown. Most species were described from very few free-living adult specimens, either males or females, and both sexes are known in only two nominal species [Trophomera australis (Petter, 1983) and $T$. petterae (Miljutin, 2004)] so far. Some species descriptions have been based on a single specimen. The 
size range of known benthimermithids varies from less than $1 \mathrm{~mm}$ to $17 \mathrm{~cm}$; however, the body length of most species is several millimeters. Miljutin (2004, 2006) reviewed the anatomy and life cycle of benthimermithids and discussed the taxonomic problems within the family. Miljutin and Miljutina (2009) produced an up-to-date key to the genera of the family Benthimermithidae and tabular keys to the species of the genus Trophomera.

As a rule, benthimermithids are quite rare and comprise a fraction of $1 \%$ of nematode assemblages (Bussau 1993; Miljutin and Miljutina 2009). Thirty-eight species of benthimermithids belonging to three genera have been described to date (Miljutin and Miljutina 2009). They have been found from the Arctic to Antarctic and throughout the Atlantic and the Indian oceans (Miljutin 2004). It is obvious that benthimermithids are widespread in the World Ocean, and their known habitat will be extended as new deep-sea areas are studied.

This contribution presents the results of a study of females belonging to the genus Trophomera from the collection of the Smithsonian's National Museum of Natural History (NMNH, Washington, DC, USA).

\section{Materials and methods}

Adult free-living nematodes were collected from sediment samples in several survey cruises in the western and southwestern parts of the Atlantic Ocean. All the cruises mentioned below were organized and carried out by the Woods Hole Oceanographic Institution (USA).

All examined specimens were selected from samples and deposited in the NMNH collection by Dr. D. G. Murphy (Smithsonian Institution, Washington, DC, USA). The USNM collection numbers are provided. Specimens were initially fixed on board with $4 \%$ formaldehyde in seawater. Nematodes were then rinsed in distilled water, transferred to anhydrous glycerol according to the progressive evaporation method (Seinhorst 1959), and mounted on a glass slide.

For the present study, nematode specimens were examined using a LEICA DMR interference microscope fitted with the $1.5 \times$ and $2 \times$ magnifier and equipped with a drawing tube.

Abbreviations:

a amph.dist. distance from anterior apex to amphid c ratio of 'body length/tail length'

$\mathrm{c}^{\prime} \quad$ ratio of 'tail length/anal body diameter'

c.b.d corresponding body diameter

d ratio of 'body length/distance from anterior apex to amphid'
L total body length

V distance from anterior end to vulva/total body length', \%

\section{Taxonomic descriptions}

Trophomera americana sp. $\mathrm{n}$.

Figures 1, 2; Table 1

Type material. Holotype: gravid female, USNM 1000098, station No. 1036 (RV "Chain", cruise 58, $39^{\circ} 43.36^{\prime} \mathrm{N}, 70^{\circ} 37.24^{\prime} \mathrm{W}$, depth 2,022 m, 04.05.1966). Paratype: virgin female, USNM 1000084, station No. 119 (RV “Atlantis II”, cruise $24,32^{\circ} 16^{\prime} \mathrm{N}, 64^{\circ} 32^{\prime} \mathrm{W}$, depth 2,095 m, 19.08.1966).

Location. Hatteras Abyssal Plain, Western Atlantic.

Etymology. Latinized form of "American".

Description

Measurements: $\mathrm{L}=3,250-4,470 \mu \mathrm{m} ; \mathrm{a}=40.6-42.6$; $\mathrm{V}=50.5-55.0 \%$ (Table 1 ).

Females. Body cylindrical, slightly narrowed at posterior end. Anterior end rounded. Posterior end conical with rounded tip. Cuticle about $3 \mu \mathrm{m}$ thick in anterior and midbody and about $8 \mu \mathrm{m}$ thick in posterior body. Four mediolateral cephalic setae about 3-4 $\mu \mathrm{m}$ long inserted in small pits. Somatic sensilla in shape of small setae 1.0-1.5 $\mu \mathrm{m}$ long arranged along hypodermal chords and present also anterior to amphids. Amphids non-spiral, situated about 1 c.b.d. from cephalic apex. Amphidial apertures oval, transversely oriented, about $4 \mu \mathrm{m}$ long. Amphidial fovea $7-10 \mu \mathrm{m}$ in diameter. Mouth opening reduced to small pit in cuticle of apex. Pharynx devoid of internal lumen and appearing as a short irregular bar. Gravid female possessing several large, optically transparent cells without intracellular inclusions anteriorly to the beginning of trophosome. Trophosome without internal lumen and consisting of several longitudinal rows of large cells. Cellular borders in trophosome distinct. Rectum and anus vestigial. Female reproductive system amphidelphic and occupying about half of body length in gravid female. Ovaries reflected. Oviduct long, at first directed away from vulva from proximal end of ovary, and then turning toward vulva, filled with eggs. Most mature eggs about $35 \mu \mathrm{m}$ in diameter, possessing large light vacuoles. Some small cells (possibly spermatozoa) present in narrow middle part of oviduct. Uterus morphologically undifferentiated. Vagina short, with thick cuticular walls. Vulvar glands absent. Male unknown. Males and host unknown. 
Fig. 1 Trophomera americana sp. n., females. a holotype, general appearance;

b, c holotype, anterior end; d holotype, reproductive system; e paratype, anterior end; f holotype, body fragment at level of trophosome; $\mathbf{g}$ holotype, posterior end. Scale bars $\mathbf{a}, \mathbf{d}=500 \mu \mathrm{m} ; \mathbf{b}, \mathbf{c}, \mathbf{e}, \mathbf{f}$, $\mathbf{g}=50 \mu \mathrm{m}$
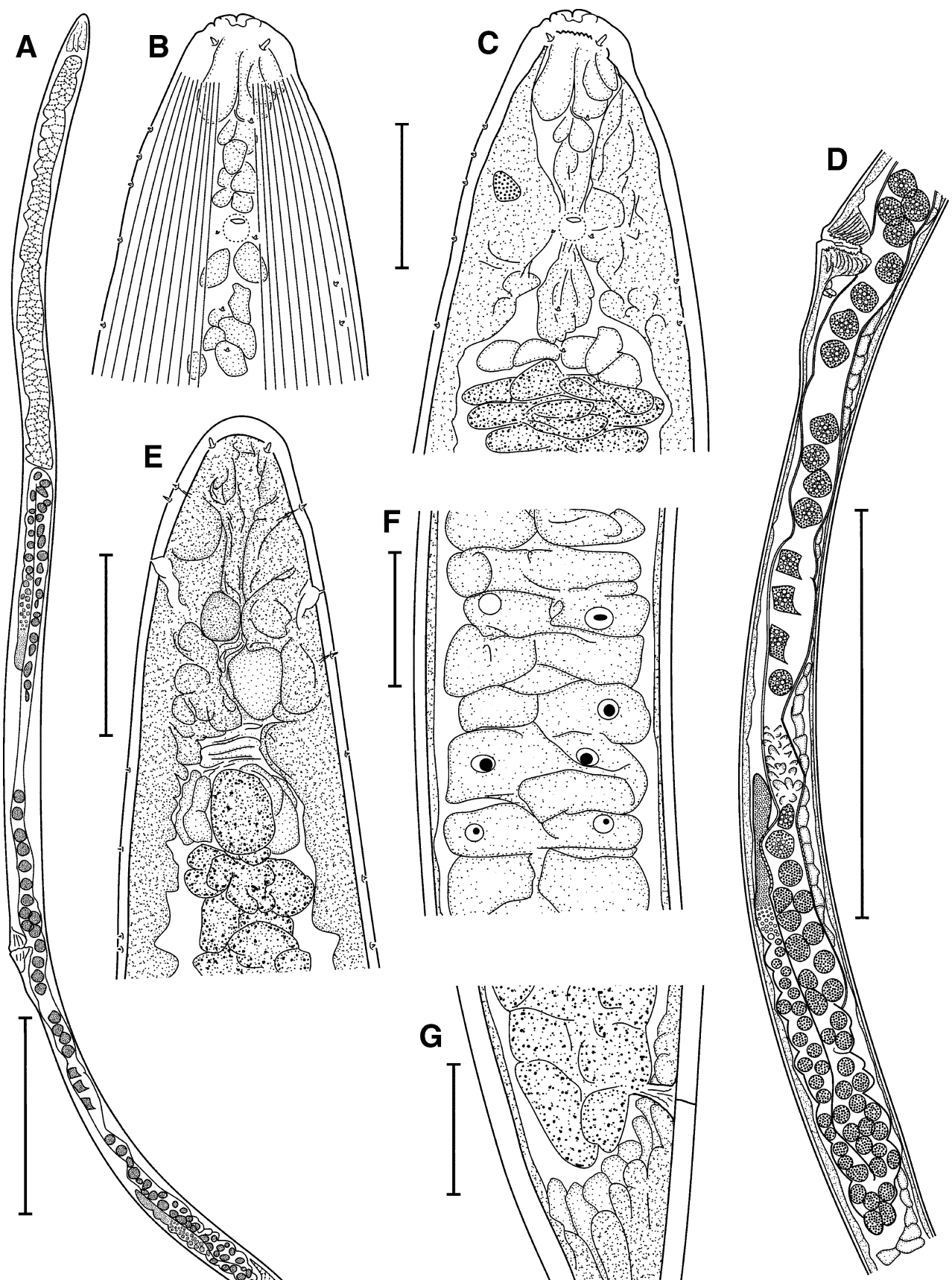

\section{Differential diagnosis}

Females of T. americana sp. n. resemble the females of T. iturupiensis (Rubtzov and Platonova, 1974), T. hureaui (Petter, 1983), T. conicauda (Petter, 1987), T. tchesunovi (Miljutin, 2004), T. elegantis Miljutin et Miljutina, 2009, and T. senckenbergi Miljutin et Miljutina, 2009, in the shape of the tail (conical with rounded tip).

$T$. americana $\mathrm{sp}$. $\mathrm{n}$. differs from $T$. elegantis and T. senckenbergi by its longer body (3.2-4.5 vs. $1.5 \mathrm{~mm}$ and $1.6 \mathrm{~mm}$, respectively); by its larger mature eggs ( $35 \mu \mathrm{m}$ in diameter vs. $24 \mu \mathrm{m}$ and $15 \times 9 \mu \mathrm{m}$, respectively); by the 
Fig. 2 Trophomera americana sp. n., micrographs, female, holotype. a, b head; c fragment of trophosome before genital system. Scale bars $\mathbf{a}$, $\mathbf{b}=50 \mu \mathrm{m} ; \mathbf{c}=200 \mu \mathrm{m}$

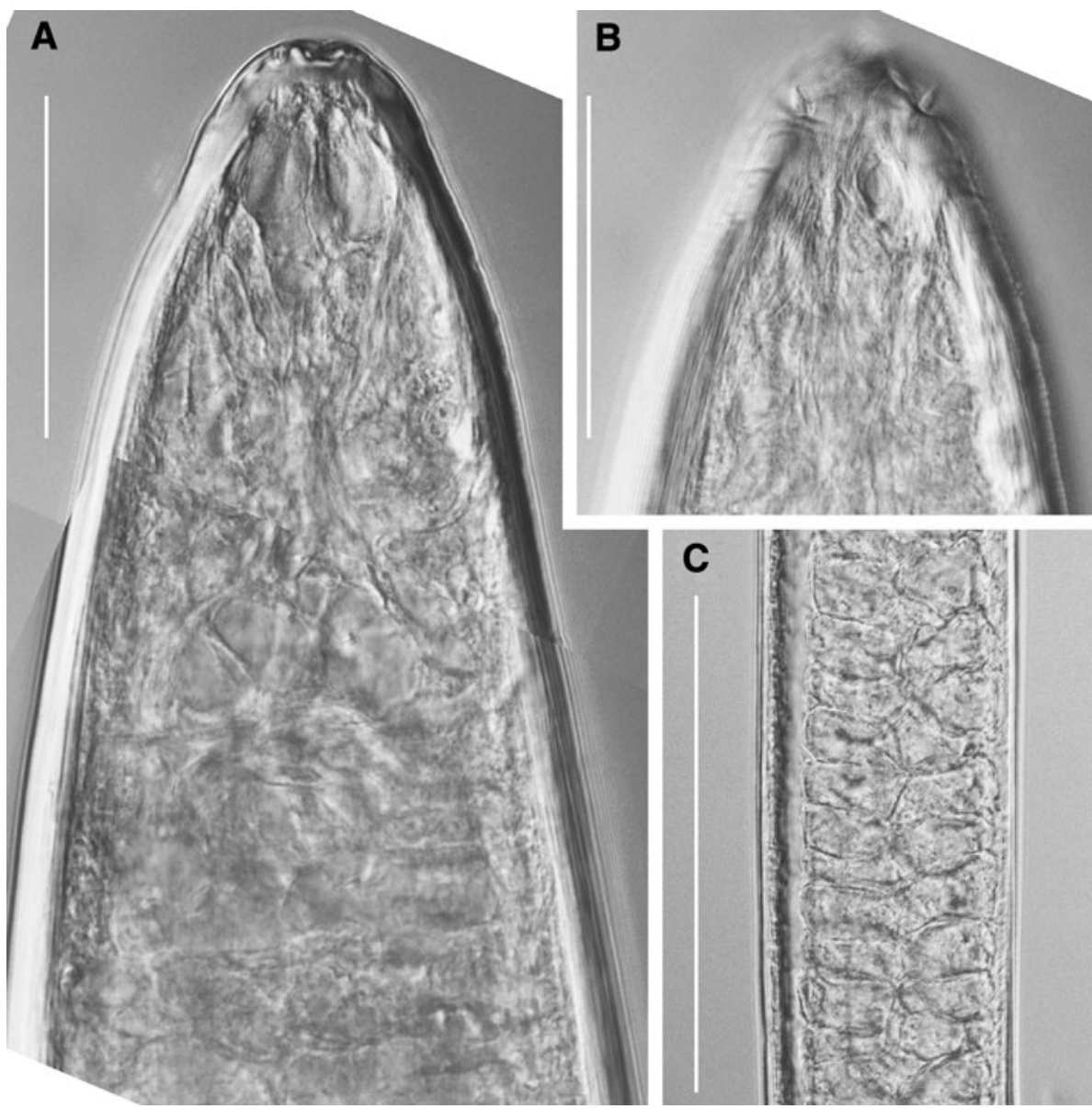

construction of the trophosome (consisting of several rows of cells, vs. one row of cells in both compared species).

T. americana $\mathrm{sp}$. $\mathrm{n}$. differs from $T$. iturupiensis by its much shorter body (3.2-4.5 mm vs. $26-38 \mathrm{~mm})$ and by its smaller "a" index (40-43 vs. 98-104).

$T$. americana sp. n. differs from $T$. conicauda by the shape of the head (rounded vs. conical with rounded tip in $T$. conicauda), by its smaller body size (3.2-4.5 vs. $5.2-6.8 \mathrm{~mm}$ ), by the relatively thicker body ( $\mathrm{a}=41-43 \mathrm{vs}$. 49-58), and by the smaller "d" index (61-69 vs. 108-148).

$T$. americana $\mathrm{sp}$. n. differs from $T$. hureaui by the relatively thinner body ( $\mathrm{a}=41-43$ vs. $25-32$ ), by its relatively short reproductive system in gravid specimens (occupying ca. 0.5 body length vs. ca. 0.25 body length), and by its larger eggs (35 $\mu \mathrm{m}$ in diameter versus $25 \mu \mathrm{m})$.

Trophomera arnaudi (Petter, 1983)

Fig. 3; Table 2

Petter 1983: 12-14, Fig. 7 (Benthimermis arnaudi); Chesunov 1988: 13-15, Figs. 1, 2 (Benthimermis arnaudi); Miljutin 2006 (Trophomera arnaudi comb. n.)

Material examined. One gravid and three virgin females found free-living. Specimen No. 1 (USNM 1000080) and
Table 1 Main measurements of females of T. americana sp. n

\begin{tabular}{lll}
\hline Specimen status & Holotype & Paratype \\
\hline Maturity & Gravid & Virgin \\
$\mathrm{L}, \mu \mathrm{m}$ & 4,470 & 3,250 \\
Amph.dist., $\mu \mathrm{m}$ & 73 & 47 \\
Tail length, $\mu \mathrm{m}$ & 90 & 103 \\
Diameter at level of cephalic sensilla, $\mu \mathrm{m}$ & 34 & 24 \\
Diameter at amphidial level, $\mu \mathrm{m}$ & 79 & 47 \\
Diameter at level of midbody, $\mu \mathrm{m}$ & 105 & 80 \\
Maximal body diameter, $\mu \mathrm{m}$ & 105 & 80 \\
Diameter at anal level, $\mu \mathrm{m}$ & 48 & 48 \\
a & 42.6 & 40.6 \\
$\mathrm{c}$ & 55.0 & 50.5 \\
$\mathrm{c}^{\prime}$ & 1.4 & 2.6 \\
$\mathrm{~d}$ & 61 & 69 \\
$\mathrm{~V}, \%$ & 50.5 & 55.0 \\
\hline
\end{tabular}

specimen No. 2 (USNM 1000105), station No. 64 (RV “Atlantis II", cruise $12,38^{\circ} 46.0^{\prime} \mathrm{N}, 70^{\circ} 06.0^{\prime} \mathrm{W}$, depth 2,886 m, 21.08.1964, NW Atlantic); specimen No. 3 (USNM 1000107), station D1 (RV “Atlantis II”, cruise $277,39^{\circ} 54.5^{\prime} \mathrm{N}, 70^{\circ} 35.46^{\prime} \mathrm{W}$, depth $467 \mathrm{~m}, 23.05 .1962$, 
Fig. 3 Trophomera arnaudi (Petter 1983), females. a specimen No. 4, general appearance; $\mathbf{b}$, c specimen No. 4, anterior end; d specimen No. 4, reproductive system; e specimen No. 3, posterior end; f specimen No. 3, anterior end; g specimen No. 4 , posterior end. Scale bars $\mathbf{a}=500 \mu \mathrm{m}$; b, $\mathbf{c}, \mathbf{f}, \mathbf{g}=50 \mu \mathrm{m}$ $\mathbf{d}=200 \mu \mathrm{m} ; \mathbf{e}=100 \mu \mathrm{m}$. Abbreviations: $a$ amphid, $h$ head, l.ch. lateral chord, $t$ trophosome

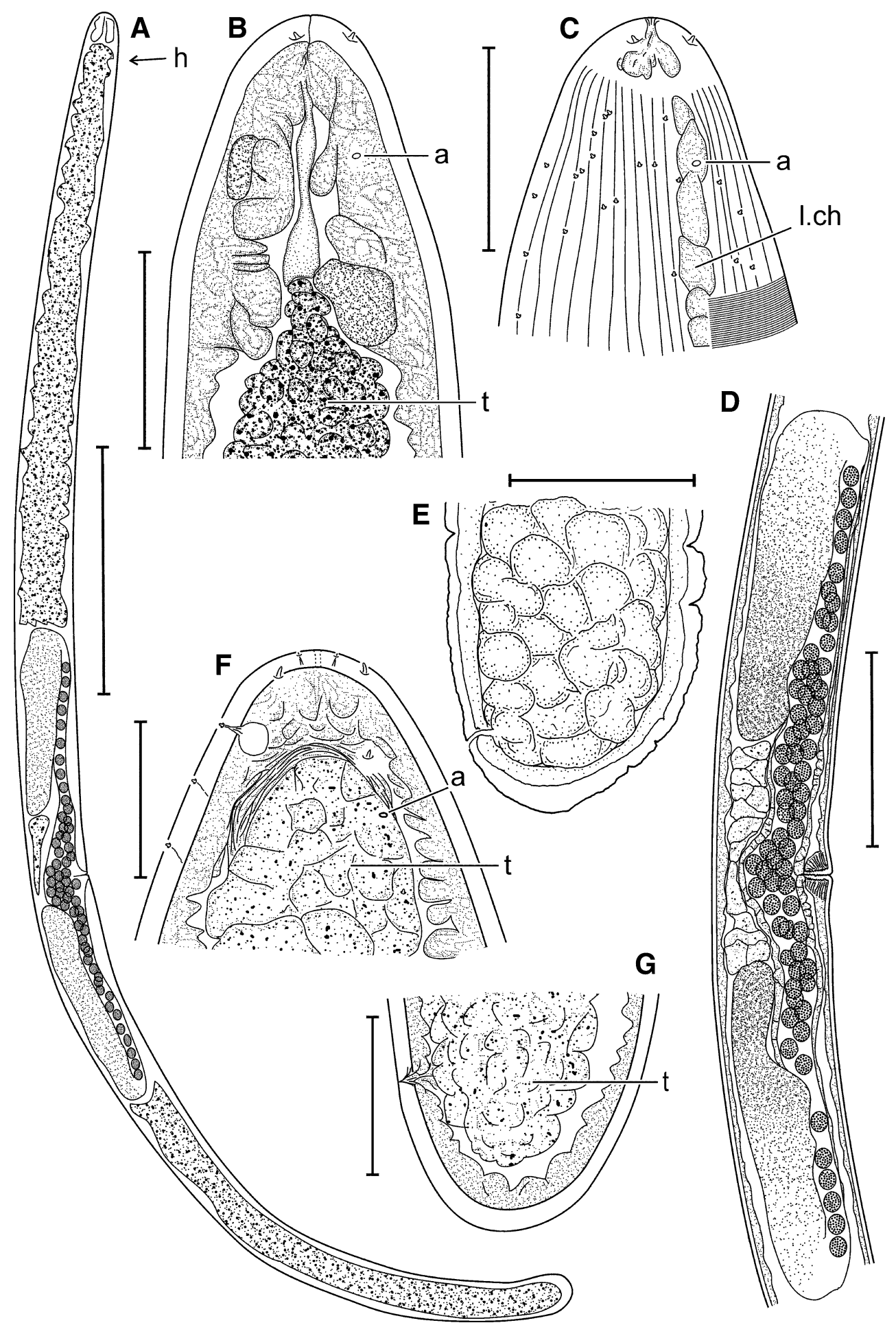

NW Atlantic); specimen No. 4 (USNM 1000113), station No. 125 (RV “Atlantis II", cruise $24,39^{\circ} 37^{\prime} \mathrm{N}, 66^{\circ} 44-47^{\prime}$ W, depth 3,806 m, 23.08.1966, NW Atlantic).

Location. Western Atlantic, off Cox Ledge.

\section{Description}

Measurements: $\mathrm{L}=3,386-8,240 \mu \mathrm{m} ; \mathrm{a}=25.3-47.1$; $\mathrm{c}=67.7-183.0 ; \mathrm{V}=49-54 \%$ (Table 2).
Females. Body cylindrical. Anterior end conical with rounded apex, posterior end rounded. Cuticle with fine annulation visible in light microscope, or lacking annulation. Cuticle about $5 \mu \mathrm{m}$ thick along entire body. Four cephalic mediolateral papilloid sensilla, from 2 to $6 \mu \mathrm{m}$ long. Each cephalic sensillum located in small pit. Ring of several tiny, very narrow labial setae ca. $1 \mu \mathrm{m}$ long seen 
Table 2 Main measurements of females of T. arnaudi (Petter, 1983)

\begin{tabular}{lllll}
\hline Specimen, no. & 1 & 2 & 3 & 4 \\
\hline Maturity & Virgin & Virgin & Virgin & Gravid \\
L, $\mu \mathrm{m}$ & 7,170 & 8,240 & 5,170 & 3,390 \\
Amph.dist., $\mu \mathrm{m}$ & 56 & 95 & 37 & 36 \\
Tail length, $\mu \mathrm{m}$ & 44 & 45 & 34 & 44 \\
Length of cephalic sensilla, $\mu \mathrm{m}$ & 5 & 6 & 3 & 3 \\
Diameter at level of cephalic & 53 & 61 & 43 & 27 \\
$\quad$ sensilla, $\mu \mathrm{m}$ & & & & \\
Diameter at amphidial level, $\mu \mathrm{m}$ & 89 & 112 & 75 & 54 \\
Diameter at level of midbody, $\mu \mathrm{m}$ & 160 & 175 & 187 & 134 \\
Maximal body diameter, $\mu \mathrm{m}$ & 164 & 177 & 187 & 134 \\
Diameter at anal level, $\mu \mathrm{m}$ & 130 & 149 & 100 & 77 \\
a & 43.7 & 47.1 & 27.7 & 25.3 \\
$\mathrm{c}$ & 163 & 183 & 152 & 77 \\
$\mathrm{c}^{\prime}$ & 0.34 & 0.30 & 0.34 & 0.57 \\
d & 128 & 87 & 140 & 94 \\
$\mathrm{~V}^{\prime} \%$ & 52.4 & 52.0 & 49.2 & 54.0 \\
\hline
\end{tabular}

anterior to cephalic papillae in specimen No. 4. Somatic setae 1-2 $\mu \mathrm{m}$ long, arranged irregularly over entire body and also anteriorly to amphid. Amphidial aperture oval, transversely oriented, about $3 \mu \mathrm{m}$ wide, situated $0.5-0.85$ c.b.d. from cephalic apex. Amphidial fovea not seen. Mouth opening reduced, present as narrow intracuticular canal at cephalic apex. Pharynx devoid of internal lumen and muscular envelope. Pharynx present as narrow bar in specimen No. 3, and body cavity filled by strongly protruded hypodermal chords. Midgut a multicellular trophosome without visible internal lumen. Cellular borders of trophosomal cells indistinct. Beginning of trophosome sometimes anterior to amphid in virgin specimens. Rectum a cytoplasmic bar connecting with narrow anal opening. Female reproductive system didelphic, amphidelphic, occupying from 0.3 to 0.5 body length. Ovaries reflected. Vagina short, with thin walls. Diameter of mature eggs in specimen No. 4 about $24 \mu \mathrm{m}$. Uterus morphologically undifferentiated and with widened proximal parts of ovaries near vulva. Vulvar glands absent in gravid specimen and present in virgin specimens. Neither morphologically differentiated spermatheca nor spermatozoa discovered.

\section{Remarks}

T. arnaudi was initially described by Petter (1983) as Benthimermis arnaudi, based on two females from the southern Indian Ocean $\left(46^{\circ} 03^{\prime} \mathrm{S}, 49^{\circ} 47^{\prime} \mathrm{E}\right.$, depth $\left.267 \mathrm{~m}\right)$. Subsequently, Chesunov (1988) reported a new find of B. arnaudi in the South Atlantic $\left(52^{\circ} 15^{\prime} \mathrm{S}, 56^{\circ} 51^{\prime} \mathrm{W}\right.$, depth $1,105 \mathrm{~m}$ ). Afterward, Miljutin (2006) reduced Benthimermis to a junior synonym of Trophomera. The new finds of T. arnaudi were made far from the previous ones, in the northwest Atlantic at depths from 467 to 3,806 m. Thus, T. arnaudi is known from two oceans (Fig. 4).

The new specimens show great similarity to those described earlier, in their general appearance; in indices "a" (25-47 vs. $24-42)$, "c" (77-183 vs. $80-335)$, “d" (87-140 vs. $97-134)$, and V (49-54\% vs. $48-56 \%)$; in the ratio "length of genital system/body length" (0.3-0.5 vs. 0.5 ); and in the diameter of the mature eggs (24 vs. 20-30 $\mu \mathrm{m})$. The main differences are in the body length: specimen No. 4 is shorter than specimens described previously ( 3,390 vs. $5,600-6,800 \mu \mathrm{m})$, whereas specimens No. 1 and 2 are longer $(7,170-8,240 \mu \mathrm{m})$. In their body length, shape of posterior end, and indices, the longer specimens resemble T. edouardensis (Petter, 1983), but their female reproductive system occupies no more than 0.5 body length, versus $0.8-0.9$ in $T$. edouardensis (even in virgin females).

Large differences in body length are known for some other species of Trophomera. For example, the differences in body length of specimens of T. turpicauda (Miljutin, 2004) are about twofold (Miljutin 2004). The same occurs
Fig. 4 Map of findings of T. arnaudi. 1 Petter 1983; 2 Chesunov 1988; 3 present work

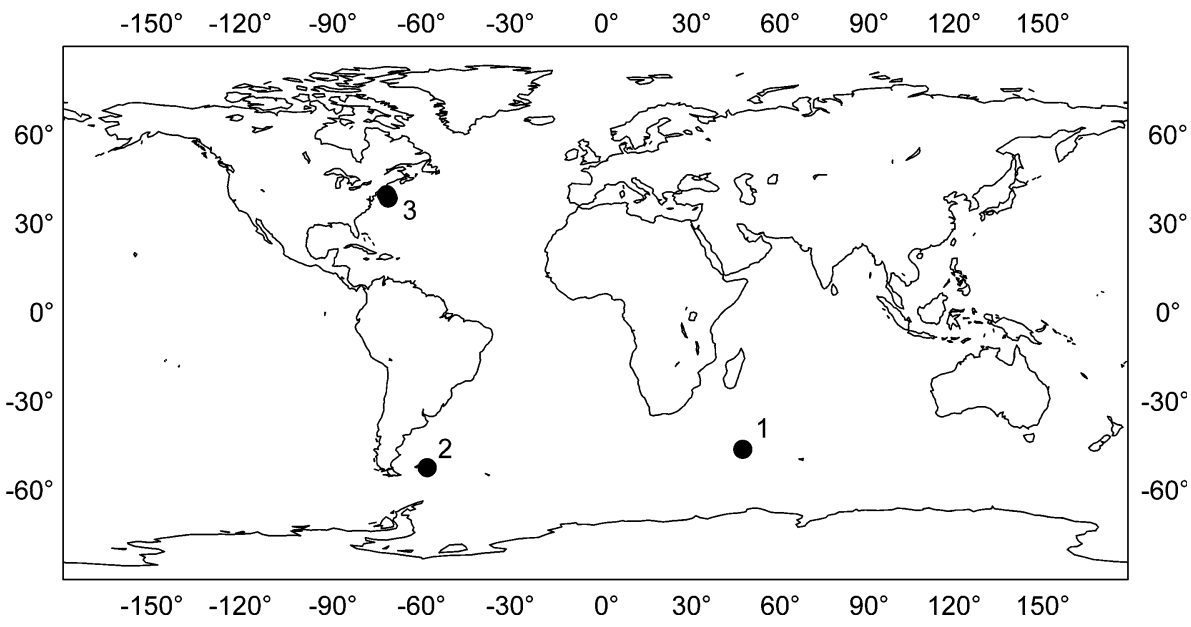


with T. megala (Petter, 1987) (Miljutin and Tchesunov 2001), and in the type series of T. acuticauda (Petter, 1981) (Petter, 1981a), T. diploptera (Petter, 1981) (Petter, 1981b), T. litoralis Miljutin, 2006 (Miljutin 2006), and T. longiovaris sp. n. (present paper). Such a wide range of body sizes within the same species may be caused by differences in the host body sizes, the number of parasitic larvae inside the same host individual (several larvae may somehow inhibit each other's growth or compete with each other for food resources), or by the different locations of larvae in different hosts. For example, parasitizing a crustacean's gonad may provide a larva with better food or allow it more space for growing, than when a larva infects an internal cavity of a crustacean's coxal plate. Parasitizing benthimermithid larvae were found both in gonads of amphipods and in internal cavities of amphipods' coxal plates (author's unpublished data).

In its general appearance and body parameters, the females of $T$. arnaudi closely resemble $T$. bathycola (Rubtzov, 1980). However, according to the original description, the former species possess reflected ovaries, in contrast to the outstretched ones in $T$. bathycola. The original description was brief and lacked detailed illustrations. It is possible that the specimens described by Rubtzov (1980) do possess reflected ovaries, and if this is the case, $T$. bathycola should be merged with $T$. arnaudi.

\section{Trophomera longiovaris sp. n.}

Figures 5, 6, 7; Table 3

Type material. Holotype: virgin female, USNM 1000112, station No. 85(2) (RV “Chain”, cruise 50, 37 $59.2^{\prime} \mathrm{N}$, 69 $26.2^{\prime} \mathrm{W}$, depth 3,834 m, 05.06.1965, NW Atlantic). Paratype: virgin female, USNM 1000102, station No. 95 (RV “Atlantis II”, cruise $38^{\circ} 33^{\prime} \mathrm{N}, 68^{\circ} 32^{\prime} \mathrm{W}$, depth 3,753 m, 12.12.1965, NW Atlantic).

Location. Hatteras Abyssal Plain, Western Atlantic.

Etymology. From Latin longa (long) and ovarium.

Description

Measurements: $\mathrm{L}=7,870-15,400 \mu \mathrm{m} ; \mathrm{a}=52.5-71.0$; $\mathrm{c}=115.7-115.8 ; \mathrm{V}=46.8-53.2 \%$ (Table 3 ).

Females. Body fusiform, narrowing slightly toward anterior and posterior ends. Anterior end rounded-conical, posterior end conical with rounded apex. Body cuticle gradually thickening from head to tail. Cuticle ca. $2 \mu \mathrm{m}$ thick at anterior end, slightly thickened posteriorly up to 5-7 $\mu \mathrm{m}$ at caudal part. Cuticle of tail forming large annular rugae. Four mediolateral cephalic sensilla ca. $7 \mu \mathrm{m}$ long. Somatic sensilla present as short conical papillae about $0.5 \mu \mathrm{m}$ long, and arranged along lateral hypodermal chords. Amphids non-spiral, situated 0.5-0.6 c.b.d. from cephalic apex. Amphidial aperture round, about $1.5-2.0 \mu \mathrm{m}$ in

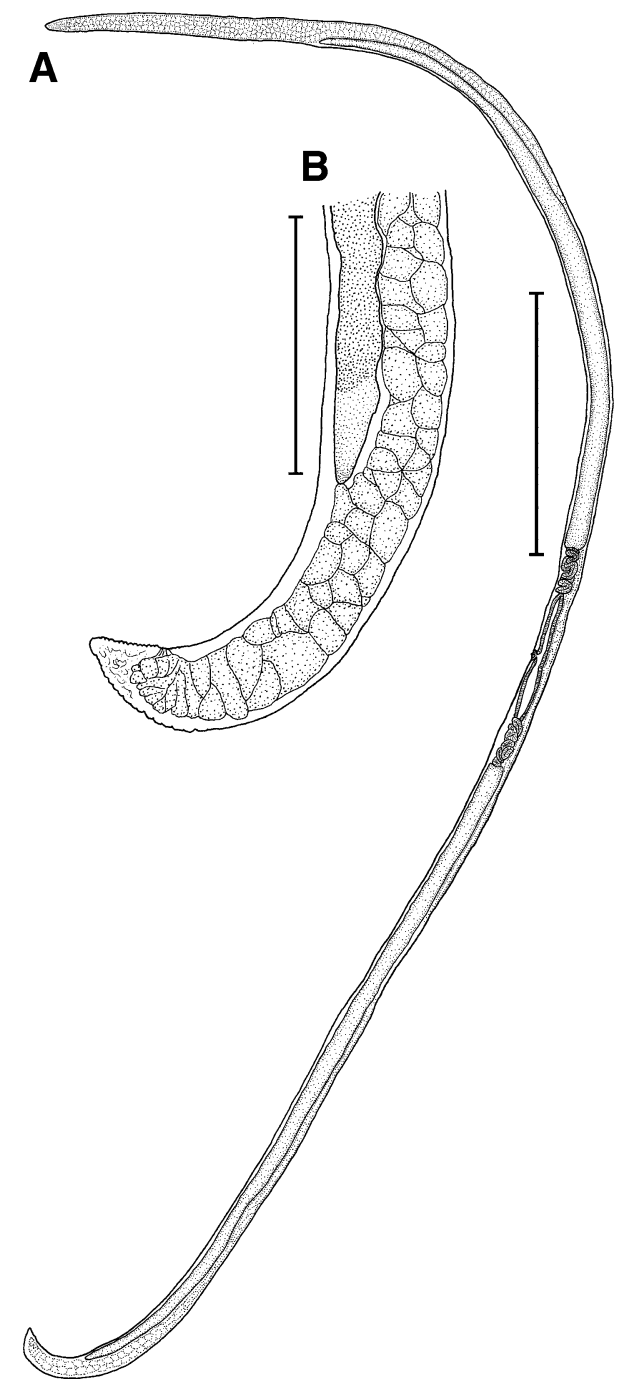

Fig. 5 Trophomera longiovaris sp. n., holotype, female. a general appearance; b posterior end. Scale bars $\mathbf{a}=2 \mathrm{~mm} ; \mathbf{b}=300 \mu \mathrm{m}$

diameter. Amphidial fovea not seen. Mouth opening vestigial, present as very narrow apical pore; cuticle at cephalic apex about half as thick as cuticle of other cephalic parts. Pharynx devoid of internal lumen and muscular envelope. Anterior part of pharynx appearing as an indistinctly formed bar, posterior part an unformed cellular mass. Midgut being a trophosome without internal lumen. Trophosomal cells arranged in 3-4 longitudinal rows anterior to and posterior to reproductive system) in an optical longitudinal section, with distinct borders and granular contents. Rectum appearing as a short bar without cuticular walls. Anus not clearly visible, appearing as a small transverse line in cuticle. Female reproductive system didelphic, amphidelphic, very long, occupying about 0.8 total body length. Ovaries telogonic, outstretched. Oviducts very long, folded repeatedly across body axis. Proximal parts of oviducts wider than distal ones, uterus distinctly formed. Vagina short, with thin walls. 
Fig. 6 Trophomera longiovaris sp. n., females. a, b holotype, general appearance; c holotype, central part of reproductive system; d holotype, posterior end; e holotype, beginning of anterior ovary; f paratype, anterior end; g paratype, posterior end. Scale bars $\mathbf{a}, \mathbf{b}, \mathbf{f}$, $\mathbf{g}=50 \mu \mathrm{m} ; \mathbf{d}, \mathbf{e}=100 \mu \mathrm{m} ;$ $\mathbf{c}=500 \mu \mathrm{m}$
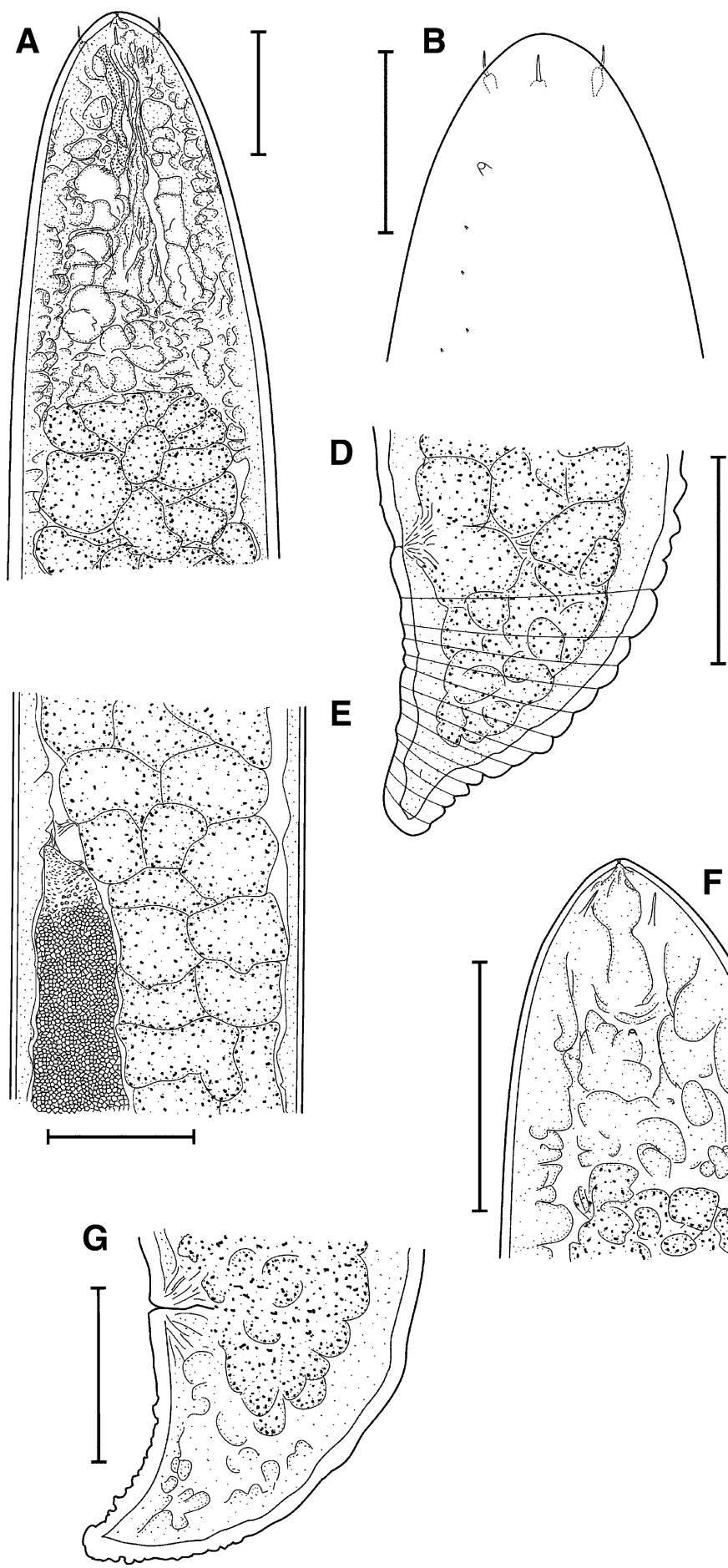
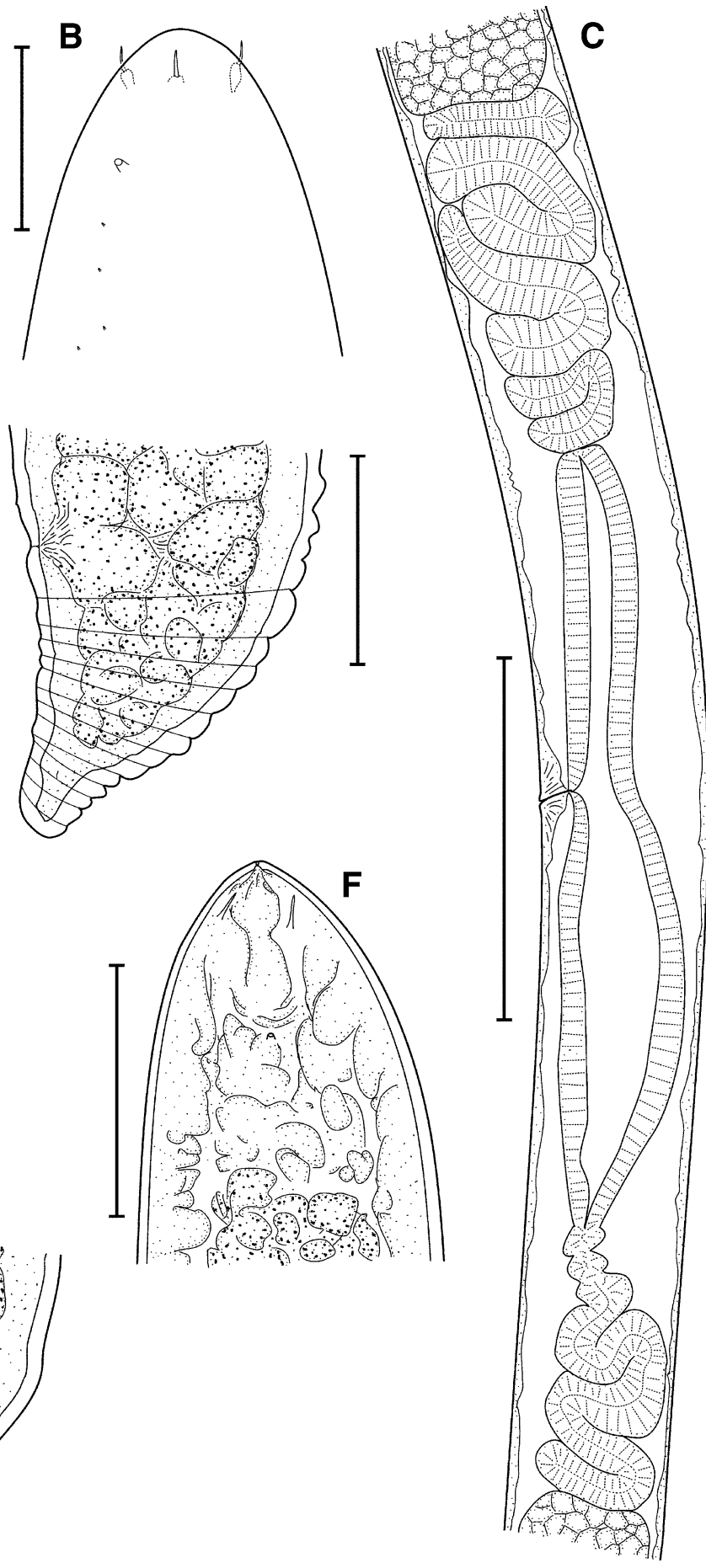

Vulva a transverse slot. Vulvar glands not developed. Neither morphologically differentiated spermatheca nor spermatozoa discovered. Males and host unknown.

\section{Differential diagnosis}

Only two known species of Trophomera possess outstretched ovaries: T. laubieri (Petter, 1987) and T. pseudominuta (Miljutin, 2004). T. senckenbergi Miljutin et Miljutina, 2009 also possesses ovaries that may be outstretched.

The female of $T$. longiovaris sp. $\mathrm{n}$. differs from the female of $T$. laubieri by its longer body (7.9-15.4 vs. 5.2-6.7 mm), "c" index (116 vs. 58-80), length of cephalic papillae $(7.0$ vs. $3.0-3.5 \mu \mathrm{m})$, and the ratio "gonad length/body length" (ca. 0.8 vs. ca 0.5). The cephalic papillae of T. longiovaris sp. $\mathrm{n}$. are not inserted in small pits, in contrast to the cephalic papillae of $T$. laubieri. 
Fig. 7 Trophomera longiovaris sp. n., micrographs, females. a holotype, head; b paratype, tail; c holotype, fragment of posterior branch of genital system; d holotype, tail. Abbreviations: an anus, g.z germinal zone of ovary, od oviduct, ov ovary, $t$ trophosome, $v$ vulva. Scale bar $200 \mu \mathrm{m}$
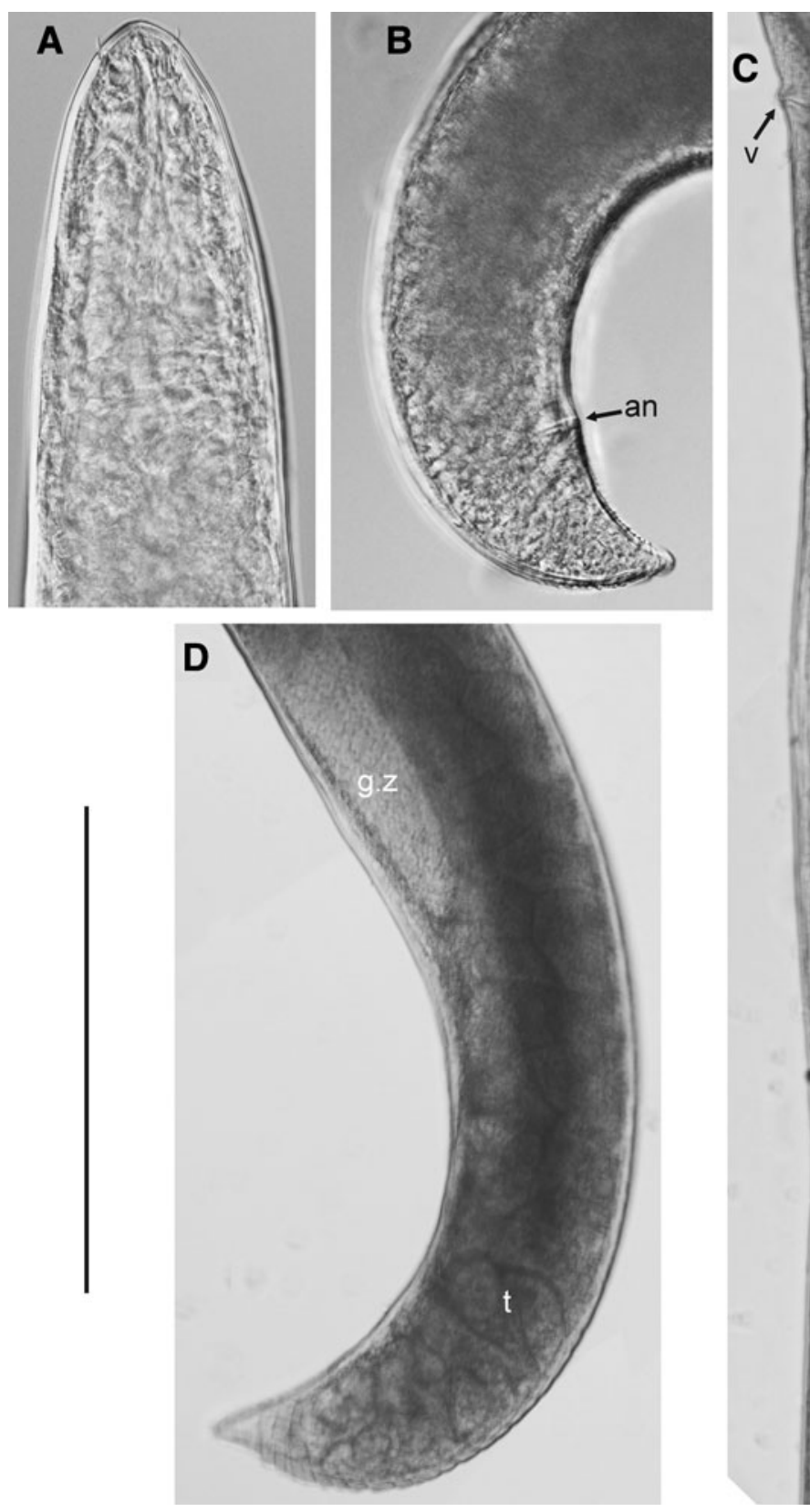

The female of $T$. longiovaris sp. n. differs from the female of $T$. pseudominuta by its much longer body (7.9-15.4 vs. $2.8 \mathrm{~mm}$ ), the "a" index (53-71 vs. 23), the ratio "gonad length/body length" (0.8 vs. 0.2$)$, and the shape of the tail (conical versus rounded).

The female of $T$. longiovaris sp. n. also differs from the female of $T$. senckenbergi by its much longer body (7.9-15.4 vs. $1.6 \mathrm{~mm}$ ); and by the de Man indices "a" and "c" (respectively 53-71 vs. 23 and 116 vs. 45).

Very long ovaries were described also in T. edouardensis (Petter, 1983) and in T. megala (Petter, 1987). However, the former species possesses reflected ovaries, and the latter has hologonic ovaries (the germinal zone extends throughout the length of the ovary) (Miljutin and Tchesunov 2001)

\section{Remarks}

The holotype is two times longer than the paratype, although both specimens are at a similar stage of maturity. However, judging by their body shape, body proportions, and the construction of the reproductive system, these specimens undoubtedly belong to the same species. Such differences in the body length have been described in other species of Trophomera (Petter 1981a, b; Miljutin and Tchesunov 2001; Miljutin 2004; present paper). 
Table 3 Main measurements of females of $T$. longiovaris sp. $\mathrm{n}$

\begin{tabular}{lll}
\hline Collection status & Holotype & Paratype \\
\hline Maturity & Virgin & Virgin \\
$\mathrm{L}, \mu \mathrm{m}$ & 15,400 & 7,870 \\
Amph.dist., $\mu \mathrm{m}$ & 40 & 37 \\
Tail length, $\mu \mathrm{m}$ & 134 & 88 \\
Diameter at level of cephalic & 35 & 27 \\
$\quad$ sensilla, $\mu \mathrm{m}$ & & \\
Diameter at amphidial level, $\mu \mathrm{m}$ & 65 & 37 \\
Diameter at level of midbody, $\mu \mathrm{m}$ & 212 & 150 \\
Maximal body diameter, $\mu \mathrm{m}$ & 216 & 150 \\
Diameter at anal level, $\mu \mathrm{m}$ & 127 & 80 \\
$\mathrm{a}$ & 71.0 & 52.5 \\
$\mathrm{c}$ & 115.8 & 115.7 \\
$\mathrm{c}^{\prime}$ & 1.1 & 1.1 \\
$\mathrm{~d}$ & 385 & 213 \\
$\mathrm{~V}, \%$ & 46.8 & 53.2 \\
\hline
\end{tabular}

The ovaries of $T$. longiovaris sp. n. are outstretched. Both examined specimens are virgin females without fertilized eggs in their oviducts and uteri. Two other species of Trophomera species possess outstretched ovaries: T. laubieri and $T$. pseudominuta, and both species were described from gravid females with eggs in their oviducts. Thus outstretched ovaries are not just a stage in the female's ontogenesis, and their structure can be used in benthimermithid taxonomy. Indeed, the structure of benthimermithid ovaries (telogonic reflected, telogonic outstretched, hologonic) is usually recognizable in virgin females.

Trophomera marionensis (Petter, 1983)

Figure 8

Petter 1983: p. 9-10, Fig. 5 (Benthimermis marionensis); Chesunov 1988: p. 15-17, Figs. 3, 4 (B. marionensis);
Fig. 8 Trophomera marionensis Petter 1983, female. a anterior end; b posterior end; c lateral hypodermal chord with glands. Scale bars $\mathbf{a}, \mathbf{c}=40 \mu \mathrm{m}$; $\mathbf{b}=100 \mu \mathrm{m}$

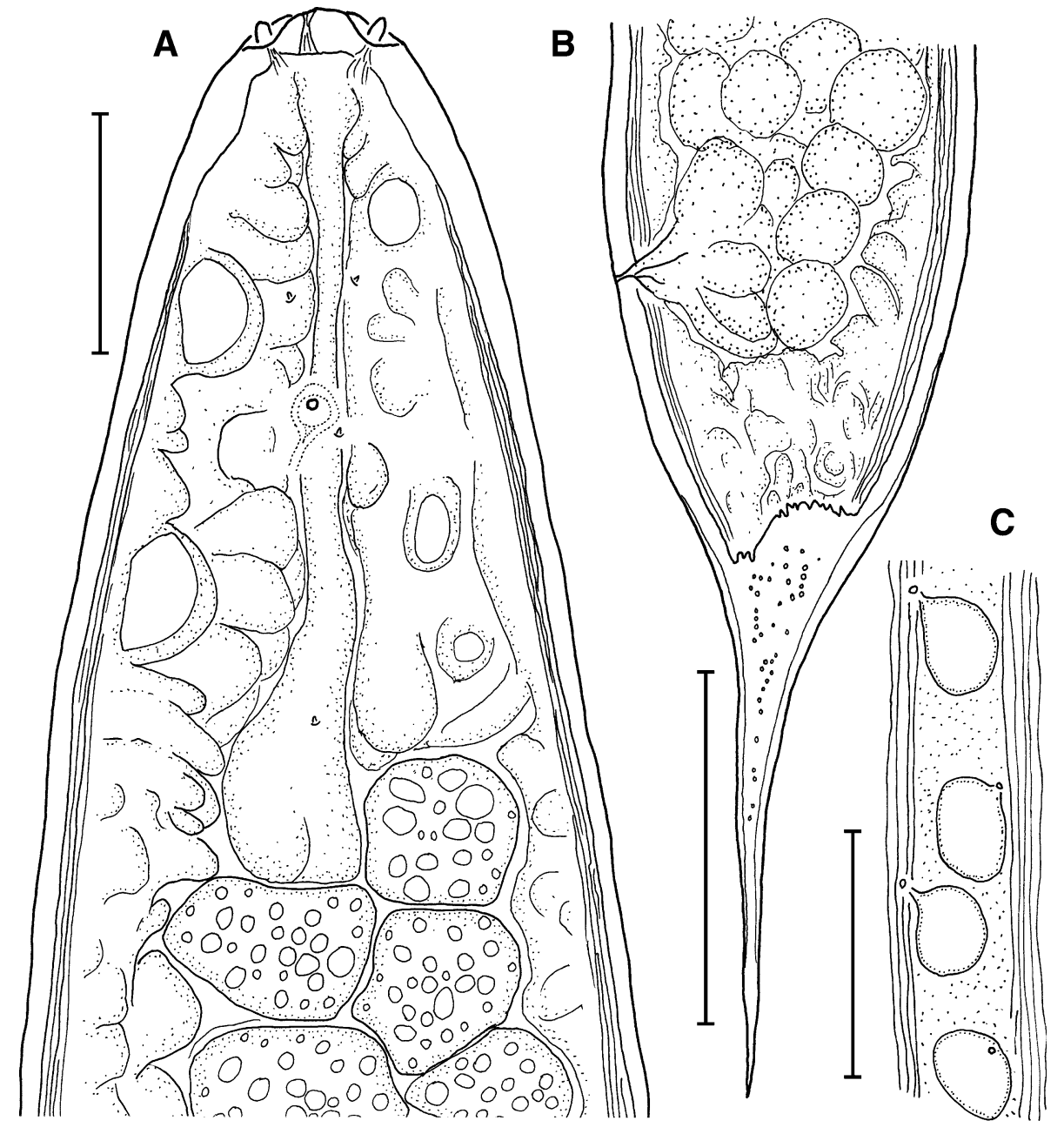


Fig. 9 Map of findings of T. marionensis. 1 Petter 1983; 2 Chesunov 1988;

3 Bussau 1993; 4 Miljutin 2004;

5 Miljutin and Miljutina 2009;

6 present work

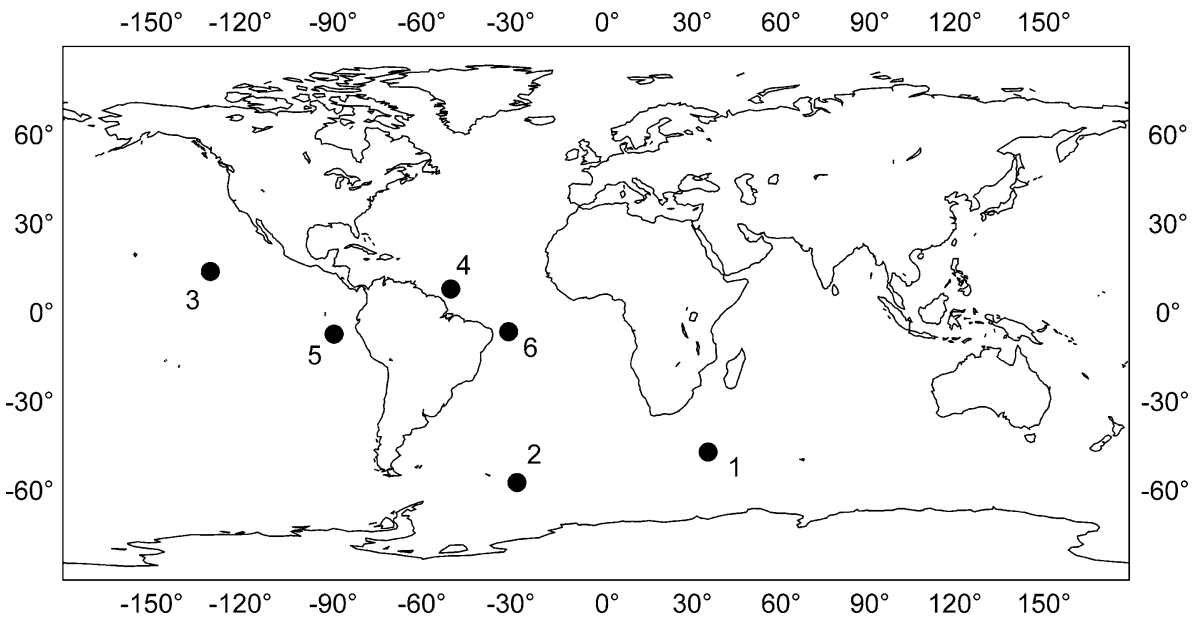

Remarks

The features of the new-found female agree very well with the description of the type by Petter (1983) in regard to the body length, the length and shape of the cephalic papillae, the shape and core structure of the caudal terminal spine, and in the De Man indices $\mathrm{a}=48.3$ and $\mathrm{V}=57.7 \%$ (versus $46.5-74.0$ and $36.9-56.8 \%$ in the type specimens).

T. marionensis was initially described from eight gravid females from the southern Indian Ocean, $46^{\circ} 52^{\prime} \mathrm{S}, 37^{\circ} 51^{\prime} \mathrm{E}$, 31-110 m depth (Petter 1983). Subsequent finds were reported by Chesunov (1988) in the South Atlantic $\left(57^{\circ} 09^{\prime} \mathrm{S}, 26^{\circ} 09^{\prime} \mathrm{W}\right.$, depth $\left.1,729 \mathrm{~m}\right)$; by Bussau (1993) in the Tropical SE Pacific $\left(7^{\circ} 04^{\prime} \mathrm{S}, 88^{\circ} 27^{\prime} \mathrm{W}\right.$, depth $\left.4,154 \mathrm{~m}\right)$; by Miljutin (2004) in the Western Atlantic $\left(8^{\circ} 07.88^{\prime} \mathrm{N}\right.$, $49^{\circ} 03.71^{\prime} \mathrm{W}$, depth $4,440 \mathrm{~m}$ ); and by Miljutin and Miljutina (2009) in the Tropical NE Pacific $\left(13^{\circ} 55.63^{\prime} \mathrm{N}\right.$, $130^{\circ} 12 \cdot 2^{\prime} \mathrm{W}$, depth $4,800 \mathrm{~m}$ ). The new specimen was found quite far from all previous locations (Fig. 9). Therefore, T. marionensis is now known from three oceans and may be considered as a cosmopolitan species (at least, until methods of molecular taxonomy are applied).

Acknowledgments The author thanks Dr. W. D. Hope (National Museum of Natural History, Smithsonian Institution, Washington, DC, USA), who kindly made available the museum's collection of benthimermithids for investigation, and Dr. A. V. Tchesunov (Moscow State University, Russia), who examined this collection and selected the specimens to be described.

\section{References}

Bussau C (1993) Taxonomische und ökologische Untersuchungen an Nematoden des Peru-Beckens. Dissertation, Christian-AlbrechtsUniversität zu Kiel, $621 \mathrm{pp}$

Chesunov AV (1988) New finds of deep-sea nematodes of the family Benthimermithidae in South Atlantic with description of a new species. Vestnik Zoologii 5:12-22 in Russian

Chesunov AV (1997) Marimermithids (Nematoda): anatomy, taxonomy, and phylogeny. Russ J Zool 1(4):440-455 
Miljutin DM (2004) New findings of deep-sea nematodes of the family Benthimermithidae Petter, 1980 with descriptions of seven new species. Zoosystema 26(1):21-48

Miljutin DM (2006) The genus Trophomera Rubtzov \& Platonova, 1974 with description of $T$. litoralis sp. n. (Nematoda: Benthimermithidae) from the tidal zone of the Kuril Archipelago and proposal of Benthimermis Petter, 1980 as a junior synonym. Nematology 8(3):411-423

Miljutin DM, Miljutina MA (2009) Description of Bathynema nodinautensis gen. n., sp. n. and four new Trophomera species (Nematoda: Benthimermithidae) from the Clarion-Clipperton Fracture Zone (Eastern Tropic Pacific), supplemented with the keys to genera and species. In: Brökeland W, George KH (eds) Deep-sea taxonomy-a contribution to our knowledge of biodiversity. Zootaxa 2096:173-196

Miljutin DM, Tchesunov AV (2001) On the histological anatomy of Benthimermis megala Petter, 1987, a giant nematode from the Norwegian deep-sea (Nematoda: Benthimermithidae). Nematology 3(6):491-502

Petter AJ (1981a) Description des mâles d'une nouvelle espèce de nématode marin de la famille des Benthimermithidae. Ann Parasitol Hum Comp 56:285-295
Petter AJ (1981b) Description des mâles de trois nouvelles espèces de nématodes de la famille des Benthimermithidae. Bull Mus Natl Hist Nat, Paris, 4-e Série, 3, Section A 2:455-465

Petter A-J (1983) Quelques nouvelles espèces du genre Benthimermis Petter, 1980 (Benthimermithidae: Nematoda) du Sud de l'Océan Indien. Syst Parasitol 5:1-15

Petter A-J (1987) Quelques nouvelles espèces de femelles du genre Benthimermis Petter, 1980 (Benthimermithidae: Nematoda) des grands fonds de la mer de Norvège. Bull Mus Nat Hist Natl Paris (3) 9 (A3):565-578

Rubtzov IA (1980) The new marine parasitic nematode, Abos bathycola, from priapulids and a taxonomic position of the family Marimermithidae in the class Nematoda. Parazitologiya 14:177-181 in Russian with English summary

Rubtzov IA, Platonova TA (1974) A new family of marine parasitic nematodes. Zool Zh 53:1445-1458 in Russian

Seinhorst JW (1959) A rapid method for the transfer of nematodes from fixative to anhydrous glycerin. Nematologica 4:67-69 